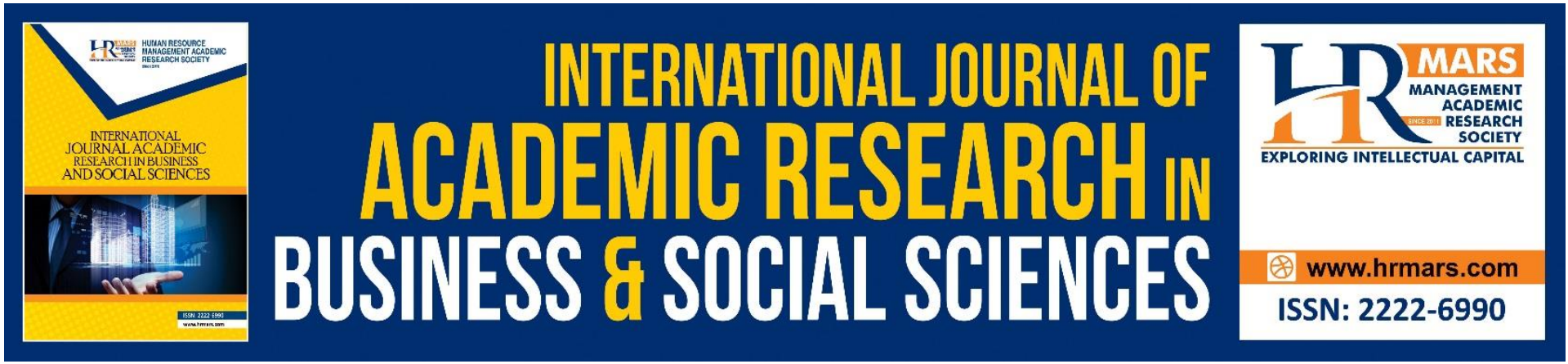

\title{
The Influence of Internal Lean Practice, Postponement, and Supply Chain Integration towards Competitive Advantage
}

\section{Nur Fathin Nadira Abdul Rasib, Veera Pandiyan Kaliani Sundram, Shereen} Noranee

To Link this Article: http://dx.doi.org/10.6007/IJARBSS/v10-i12/8041

DOI:10.6007/IJARBSS/v10-i12/8041

Received: 01 November 2020, Revised: 27 November 2020, Accepted: 20 December 2020

Published Online: 30 December 2020

In-Text Citation: (Rasib et al., 2020)

To Cite this Article: Rasib, N. F. N. A., Sundram, V. P. K., \& Noranee, S. (2020). The Influence of Internal Lean Practice, Postponement, and Supply Chain Integration towards Competitive Advantage. International Journal of Academic Research in Business and Social Sciences, 10(12), 733-744.

Copyright: (c) 2020 The Author(s)

Published by Human Resource Management Academic Research Society (www.hrmars.com)

This article is published under the Creative Commons Attribution (CC BY 4.0) license. Anyone may reproduce, distribute, translate and create derivative works of this article (for both commercial and non-commercial purposes), subject to full attribution to the original publication and authors. The full terms of this license may be seen at: http://creativecommons.org/licences/by/4.0/legalcode

Vol. 10, No. 12, 2020, Pg. 733 - 744

http://hrmars.com/index.php/pages/detail/IJARBSS

JOURNAL HOMEPAGE

Full Terms \& Conditions of access and use can be found at http://hrmars.com/index.php/pages/detail/publication-ethics 


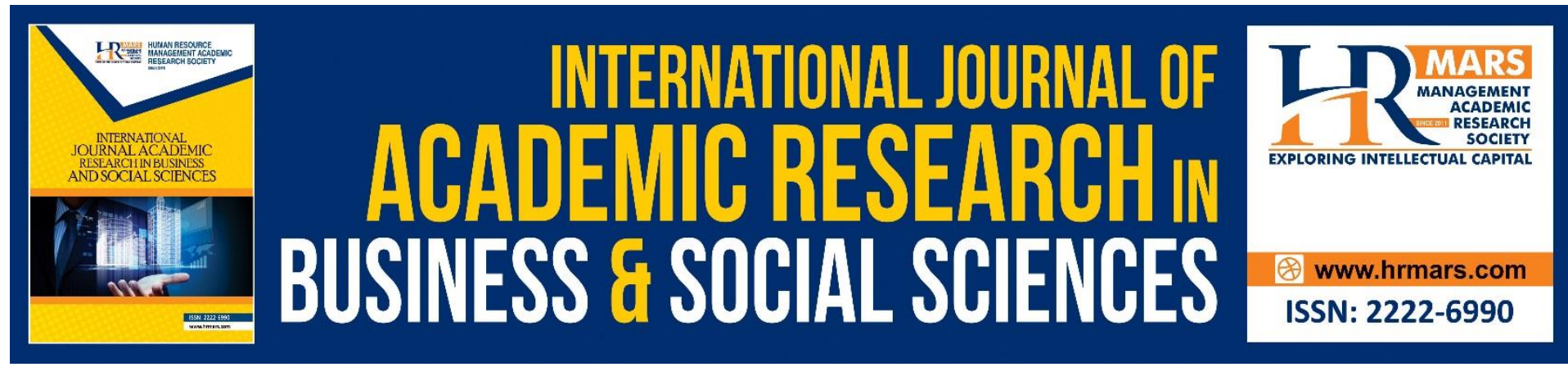

\section{The Influence of Internal Lean Practice, Postponement, and Supply Chain Integration towards Competitive Advantage}

\section{Nur Fathin Nadira Abdul Rasibํ, Veera Pandiyan Kaliani Sundram ${ }^{2}$, Shereen Noranee ${ }^{3}$}

${ }^{1}$ Faculty of Business and Management, Universiti Teknologi MARA (UiTM), 40450 Shah Alam, Selangor, Malaysia, ${ }^{2}$ Department for Technology \& Supply Chain Management Studies, Faculty of Business and Management, Universiti Teknologi MARA, UITM Kampus Puncak Alam, 42300 Bandar Puncak Alam, Selangor, Malaysia, ${ }^{3}$ Faculty of Business and Management Universiti Teknologi MARA, UITM Kampus Puncak Alam, 42300 Bandar Puncak Alam, Selangor, Malaysia

Email: fathinadirashlyn@gmail.com, veera692@uitm.edu.my, shereen@uitm.edu.my

\section{Abstract}

The purpose of this study is to explore the relationship between supply chain management practices (SCMP) and competitive advantage (CA) among manufacturing firms in Malaysia. In line with the following objectives, this study applies a quantitative research approach which will utilize stratified sampling technique and self-administered questionnaire surveys. The respondents for this survey will be the senior managers in operational management levels of various manufacturing firms in Malaysia. Subsequently, the survey data will be analysed to test the research framework and hypotheses. The results of the study can be useful for supply chain practitioners and manufacturers in integrating the appropriate SCMPs to improve supply chain performance and enhance competitive advantage. Additionally, industrial practitioners will also receive insight on how to account for the impact of SCMPs when developing their supply chain for stronger manufacturing performance by establishing competitive advantage. Many organizations are not clear regarding which practices to implement, resulting from poor understanding of what constitutes a thorough set of SCMPs. The results will also suggest successful dimensions of SCMPs that could be implemented in the effort to obtain competitive advantage in the manufacturing industry in Malaysia.

Keywords: Supply Chain Management Practices, Competitive Advantage, Manufacturing Firm.

\section{Introduction}

Taghipour et al. (2015) posit that improvement in the overall supply chain performance can lead to improvements in the overall company performance. This is because improved supply chain performance has been associated with the improvement of the overall business efficiencies (Bosch, 2017). In recognising the increasing importance of the role of supply 
chains, firms have over the years sought to work on their supply chain practices, the nature and degree of collaboration with suppliers, the nature and extent of information sharing and the overall supply chain competence.

Moreover, according to Teece (2010), field of logistic view the innovation as a temperature control technology which had a big effect on the way companies do business, as these innovations influenced the size of the value network. In order to developing in novative supply chains, Min and Mentzer (2015) found that the firm must determine its various capabilities of logistics. As logistics are an essential part of supply chain Min and Mentzer (2015), firms cannot develop an innovative supply chain without integrating the dominant logistics capabilities. Specific logistics process and practices need to be unified to ensure undisrupted flow of materials from suppliers to customers (Stock et al., 2012). Industrial firms often have time and space utilities made being available through efficient logistics integration (Flynn et al., 2010).

\section{Research Gap}

In today's highly competitive global market, the potential for growth is very promising and the development and continuing evolution of the supply chain role are obvious in the past few decades (Gundlach et al., 2019; Harvey, 2016).

Particularly in Malaysia, there are the remarkable expansion of the supply chain in manufacturing industry. Supply chain has become a significant driving force in the development of the world economy (Wang, 2018; Azar, 2017). In the past, companies are not aware of the advantage of having an effective ecosystem and thus have not given sufficient priority to the development of effective SC strategies. If this continuously persist, then it will affect the operation and production of an organization, where the uncontrollable disruptions would lead to poor profitability of the company.

Therefore, to remain competitive in the market, manufacturers must quickly respond to customer demands. Narayanan and Moritz (2015); Rezaei and Azar (2017) have demonstrated how the growing complexity of the supply chain has resulted in higher expectation of service among customers. The company's supply chain must be innovative to meet the ever-changing customer needs (Hong and Jeong, 2006; Tarafdar and Qrunfleh, 2017). Manufacturers must analytically derive solutions that can simplify disruptions and limit the cost of the recovery process (Schmitt et al, 2017; Zhen et al, 2016). Manufacturers must recognize the stages of production that will allow individuals to make the right decision while incorporating innovative ideas and policies (Croson et al., 2013; Clemons and Slotnick, 2016; Thaler, 2016).

\section{Overview of Supply Chain}

Supply chains strive to maintain internal health and environmental sustainability using the capability to self-correct based on information from the external environment (Vachon, 2007). Hence, both internal and external factor are important to form an environmental sustainability through supply chain. Handfield and Nichols (2002) had suggested that supply chain management includes all the activities associated with the flow and transformation of goods, from raw material suppliers to end consumers. It also encompasses all information flows up and down the supply chain Lambert et al. (1998) \& Gayer and Jackson (2004) concur that the supply chain is a set of business entities that directly involves in the upstream or downstream flows of products, services, and information from a secure to a customer. This definition sets the consumer at the end of the supply chain and reflects a linear production 
paradigm that assumes constant inputs of natural resources and an unlimited capacity to assimilate waste.

\section{Supply Chain Management Practices}

Supply chain management (SCM) can be defined as the configuration, coordination and continuous improvement of an organized set of operations. Its goal is to provide maximum customer service at the lowest cost possible, where a customer is anyone who uses the output of a Process. Since the goal of a company is to maximize profits, it must weigh the benefits versus the costs of its decisions along the supply chain (Chima, 2007).

Sandhu (2013) stated that SCM practices are regarded as operational functions and main activities in the firm, which determines the effectiveness and efficiency of its supply chain. The main goal of SCM concept is to enhance the long-term competitive firms' performance and their supply chains by integrating their functions, processes, and operations internally and externally with other partners. These partners mainly include the suppliers, manufacturers, distributers, and customers (Li et al., 2006). SCM encompasses various activities such as planning and management, procurement, coordination, collaboration, outsourcing and all other logistics management activities with other channel partners (Soosay et al., 2015). Majority of the studies have emphasized that the ultimate goal of SCM is to enhance and improve the performance of firms (Li et al., 2006; Chen and Chang, 2013; Min and Mentzer, 2015).

\section{Dimensions}

Many authors studied supply chain management practices and there are various elements and dimensions have measured or used to measure the supply chain practice, for more exploration in the following table some of them:

\begin{tabular}{|c|c|c|}
\hline No. & Author & Dimensions \\
\hline 1 & $\begin{array}{l}\text { Kumar et } \\
\text { al. (2018) }\end{array}$ & $\begin{array}{l}\text { Strategic supplier partnerships, level of information sharing, quality of information, } \\
\text { customer relationship management, internal lean practices, postponement, total quality } \\
\text { management }\end{array}$ \\
\hline 2 & $\begin{array}{l}\text { Porter } \\
(2012)\end{array}$ & $\begin{array}{l}\text { Information sharing, customer relationship, strategic supplier partnership, material flow } \\
\text { management and corporate culture }\end{array}$ \\
\hline 3 & $\begin{array}{l}\text { Chow et } \\
\text { al. (2008) }\end{array}$ & $\begin{array}{l}\text { There are four elements (suppliers and customer management, information sharing, } \\
\text { speed of communication, supply chain features) }\end{array}$ \\
\hline 4 & $\begin{array}{l}\text { Min and } \\
\text { Mentzer } \\
(2015)\end{array}$ & $\begin{array}{l}\text { There are seven elements of supply chain practice such as a greed vision and goals, } \\
\text { information sharing, risk and award sharing, cooperation, process integration, long-term } \\
\text { relationship and a greed supply chain leadership }\end{array}$ \\
\hline 5 & $\begin{array}{l}\text { Li et al } \\
(2006)\end{array}$ & $\begin{array}{l}\text { Vision and goals, information-sharing, risk-sharing and achievement, cooperation, } \\
\text { integration processes, long-term relationship, and supply chain leadership }\end{array}$ \\
\hline 6 & $\begin{array}{l}\text { Alvarado } \\
\text { and } \\
\text { Kotzab } \\
(2001)\end{array}$ & $\begin{array}{l}\text { Using inter-organizational system in supply chain practice such as EDI, and elimination of } \\
\text { excess stock levels by postponing customization toward the end of the supply chain }\end{array}$ \\
\hline 7 & $\begin{array}{l}\text { Handfield } \\
\text { and } \\
\text { Nichols } \\
\text { (2002) }\end{array}$ & Supply chain practice includes purchasing quality, and customer relations \\
\hline
\end{tabular}

Table 1. Dimensions of SCMPs. Adapted from Yunis, Kassar, and Tarhini (2017). 
The literature portrays SCM practices from a variety of different perspectives with a common goal of ultimately improving organizational performance. Additionally, Yunis et al. (2017) posited the other practices are essential for companies to have a competitive edge over their competition. The best supply chain management practices (SCMPs) have become an essential factor for low-performing firms to remain competitive in the global race (Okongwu et al., 2015). The nature of SCMPs will be able to explain the dual purpose of SCM as it improves the performance of an individual firm as well as the performance of the whole supply chain.

\section{Internal Lean Practice}

Lean has gained popularity in a wide range of industrial sectors, beyond manufacturing, all around the world (Kumar et al., 2018). It is nowadays considered the most influential new paradigm in manufacturing Reuter et al., (2010), enhancing the competitiveness of organizations (Hines, 2004). Lean is focused on identifying and eliminating waste in a product's entire value stream, extending not only within the organization, but also along its entire supply chain network (Boyle et al., 2009). Thus, the concept of lean supply chains has been widely studied in the academic literature (Chen and Chang, 2010; Tarafdar and Qrunfleh, 2017). In most of the cases, these studies suggest that lean principles and practices enable the effective management of supply chains. This evidence contributed in considering this dimension as part of the SCMPs construct developed for this study.

P1: $\quad$ Lean practices has a positive effect on competitive advantage.

\section{Postponement}

Postponement is defined by Li et al. (2006) as "the practice of moving forward one or more operations or activities (e.g., making, sourcing, and delivering) to a much later point in the supply chain". Its main objective is to push final product completion as close to the final customer as possible in order to reduce inventories and minimize risk of unsold product Soosay et al. (2015) or delaying further investment in a product or service until the last possible moment in order to satisfy the preferences of the customer at that moment. This factor has been widely studied, tested and validated in the SCM literature by, among other authors, Soosay et al. (2015) and Li et al. (2006). Two major considerations in developing a postponement strategy are (1) how much delay is needed, and (2) which steps should be taken to achieve the delay Postponement strategies allow a company greater flexibility in developing products that meet the changing needs of consumers and in differentiating a product to modify the demand function. These strategies are important because they relate to types of products, market demand, and structural bottlenecks in manufacturing systems and logistics (Cooper and Pagh, 1998).

P2: $\quad$ Postponement has a positive effect on competitive advantage.

\section{Supply Chain Integration}

Supply chain integration (SCl) links a firm with its customers, suppliers and other channel members by integrating their relationships, activities, functions, processes and locations (Narasimhan and Kim, 2002; Naslund and Hulthen, 2012). SCl includes two stages: internal integration between functions and external integration with trading partners. Internal integration establishes close relationships between functions such as shipping and inventory or purchasing and raw material management Groznik and Trkman (2006). While external integration has two directions: forward integration for physical flow of deliveries between suppliers, manufacturers, and customers and backward coordination of information 
technologies and the flow of data from customers, to manufacturers, to suppliers (Frohlich and Westbrook, 2001; Swink, 2015).

P3: $\quad$ Supply chain integration has a positive effect on competitive advantage.

\section{Competitive Advantage}

Competitive advantage is the extent to which an organization is able to create a defensible position over its competitors (Li et al., 2006). It comprises capabilities that allow an organization to differentiate itself from its competitors and is an outcome of critical management decisions (Thatte, 2007). The empirical literature has been quite consistent in identifying price/cost, quality, delivery, and flexibility as important competitive capabilities (Li et al., 2006). In addition, recent studies have included time-based competition as an important competitive priority. Research by Handfild and Nichols (2002), Kessler and Chakrabarti (1996), \& Zhang and Jiang (2016) identifies time as the next source of competitive advantage.

Competitive advantage exists when a firm has a product or service that is perceived by its target market customers as better than that of its competitors. Competitive advantage is composed of the action results and managerial decisions which result in the organization's superior performance when compared to those of their competitors Barney (1991) and De Guimaraes (2016). Competitive advantages pertain to a firm's ability to show a higher degree of competitiveness as compared to its rivals within a given industry, such as being able to reduce cost, creating distinct products or services, or better satisfy customers (Porter, 2012). A firm is said to have competitive advantage when the existed or potential competitors cannot duplicate or it will cost much to imitate. Besides being significantly different from competitors, firms have to consider other key success factors, such as being able to cope with environmental changes and resist the actions of competitors (Aaker, 2008).

\section{Relationship between Supply Chain Management Practices and Competitive Advantage}

Supply chain management (SCM) enhances organizational competitiveness by integrating the internal functions within a company and linking them with the external operations of suppliers, customers and other channel members (Han et al., 2007). Bagchi (1996) classified metrics for competitiveness of organizations as time, quality, cost, efficiency, and diagnostic measures. Companies that are able to offer goods at lower prices and higher quality will be able to increase sales, which, in turn, will increase profit margin and return on investment (Anatan, 2014). Davis (2007) implies that firms can develop future competitive advantage by using sustainable supply chain management and proposes that this is possible through accordance with the "triple bottom line" to improve their competitiveness. Hyland and Beckett (2002) quoted that for organizations to remain competitive should have high level of internal learning that refines both current practices and adopts new ones. Udomleartprasert and Junghirapanich (2003) in their study on aligning the infrastructure to supply chain practices quoted that manufacturing organizations gain competitive advantage by implementing value-added activities.

The organizations strive to achieve competitive advantage through satisfying customers, quick response, cooperation and coordination in sharing information, increasing sales, cost reduction, and use of management philosophies (JIT, lean production etc.). The previous study from Anatan (2014); Darwish et al (2020) resulted that supply chain management practices have significant effects on supply competitive advantage. Supply chain management includes a variety of practices carried out within an organization to achieve and 
maximize effectiveness by managing the flow of finished goods, services.

The results of the current study indicated that either Researchers have shown, however, that Supplier Relationship Management has little to no effect on Supply chain management processes address the five market forces (Boer, 2012). Supplier Relationship Management relates to the bargaining power of the supplier Competitive Advantage for the surveyed firms. The bargaining power of the suppliers is not that important to Competitive Advantage, or that the Supplier and information from point of origin to point of consumption through a set of directly linked organizations in the chain.

\section{Related Theory between Relationship of Supply Chain Management Practices and Competitive Advantage}

Competition theory describes the five forces in a market that can affect the position of the firm in the market, as discussed by (Porter, 2012). The forces revolve around the bargaining power of the supplier, bargaining power of the buyers, threats of a substitute product, the threat of new entrant in the market, and the rivalry between existing competitors in the current market. According to Porter (2012), these forces maintain the market in equilibrium, and the firm

According to Porter (2012); , these forces maintain the market in equilibrium, and the firm that could master those forces could influence the direction of the market. For a company to be effective within a marketing force, the firm must gain have competitive advantage in order to be influential within that force (Davis, 2007).

Relationship Management process is not addressing the force properly. The customer relationship management process affects the bargaining power of the buyer Kapoor and Adner (2012). Product Development and Commercialization processes can address threats of substitute products through continuous development.

\section{Framework}

\section{$\underline{\text { Independent Variable }}$}

Dependent Variable

Supply Chain

Management

Practices

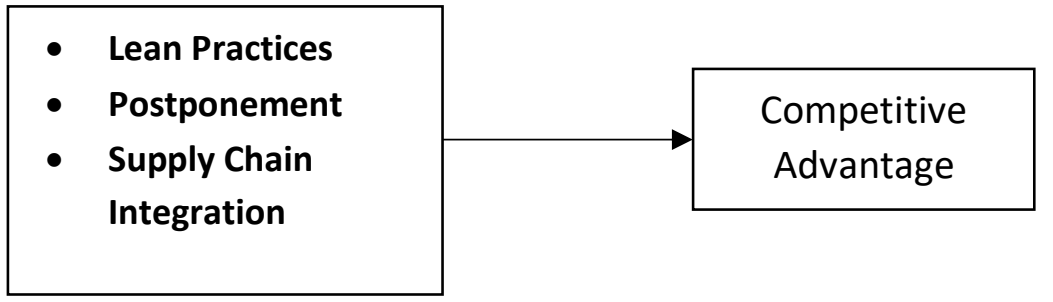

Figure 1. Conceptual Framework.

\section{Discussion}

Narasimhan and Kim (2002) in his LISREL analysis on small and large manufacturing firms found that in small firms, efficient supply chain integration helps in sustainable performance improvement. On the other hand, in large firms, the close relationship is predicted between SCM practices and competitive capability. Based on past studies, supply chain management 
and retailer performance stated that in modern retail the retailers have to deal with intense competition both domestically and globally due to changes in customer expectations. Therefore, the competitive advantage is the embodiment of firm performance, and the implementation of supply chain management can enhance a firm's competitive advantages and improve business performance.

\section{Policy Implications}

This study has benefitted to all practitioners, academician, researchers, policy makers, and government administration in Malaysia and globally. In this competitive market, an organization should be intelligent in utilizing the resources at hand and devising a plan to strive forward where all information at hand and with the coming of industry 4.0 that make it more challenging. As for the government, a researcher should start embrace more the supply chain management practices.

This is in line with the third Industrial Master Plan (IMP) (2006-2020) in Malaysia which to enhance the capabilities on supply chain and make Malaysia a competitive nation. The objective of Third-IMP, Malaysian Investment Development Authority (2007), which to achieve long-term global competitiveness through transformation and innovation of the manufacturing and service sector. Third IMP play a major role in developing and promoting Malaysian brands to become globally competitive. It also aims in encouraging industries to focus on core competencies and strengths within regional also global networks.

This study also can be an eye opener for the government and industry to help Malaysia's Education in promote more courses related to supply chain and logistics management to equip more professionals with the right supply chain knowledge, and to continuously embrace new technologies to keep up with global demand. Having a workforce with strong supply chain knowledge gives an added advantage to Malaysia, and it would enhance Malaysia's reputation as the most ideal supply chain hub.

\section{Conclusion}

Previous study mentioned that study on supply chain management and retailer performance stated that in modern retail the retailers have to deal with intense competition both domestically and globally due to changes in customer expectations. As a result, the retailers look beyond their organizational boundaries to evaluate, integrate resources and capabilities of their suppliers and customers. This helps them to create a superior value and long-term competitive advantage. They further added that retail managers focus on three major supply chain trends; global sourcing practices, multi-channel route to market, and relationship-based innovation for competitive advantage.

Therefore, the competitive advantage is the embodiment of firm performance, and the implementation of supply chain management can enhance a firm's competitive advantages and improve business performance. Therefore, the study from Jia and Wang (2019), SCM practices are positively related to competitive advantages.

\section{References}

Aaker, D. A. (2008). Strategic market management. International Journal of Operations Management.

Alvarado, U. Y., \& Kotzab, H. (2001). Supply chain management: the integration of logistics in marketing. Industrial Journal marketing management, 30(2), 183-198. 
Anatan, L. (2014). Factors influencing supply chain competitive advantage and performance. International Journal of Business and Information, 9(3).

Azar, A. (2017). A fuzzy cognitive mapping model for service supply chains performance. Measuring Business Excellence, 21(4), 388-404.

Bagchi, P. K. (1996). Role of benchmarking as a competitive strategy: the logistics experience. International Journal of Physical Distribution \& Logistics Management.

Barney, J. (1991). Firm resources and sustained competitive advantage. Journal of Management, Vol. 17 No. 1, pp. 99-120.

Boer, H. (2012) Enabling globalization of manufacturing through supply chain improvement programs. In 4th P\&OM world conference, EurOMA-POMS-JOMSA.

Bosch, O. J. (2017). Identifying key success factors in supply chain management for increasing the competitive advantages of Vietnamese coffee. Competitiveness Review: An International Business Journal.

Chen, I. J., \& Paulraj, A. (2004). Towards a theory of supply chain management: the constructs and measurements. Journal of operations management, 22(2), 119150.

Chen, Y. S., \& Chang, C. H. (2013). Enhance environmental commitments and green intangible assets toward green competitive advantages: an analysis of structural equation modeling (SEM). Quality \& Quantity, 47(1), 529-543.

Cherrafi, A., Garza-Reyes, J. A., Kumar, V., Mishra, N., Ghobadian, A., \& Elfezazi, S. (2018). Lean, green practices and process innovation: A model for green supply chain performance. International Journal of Production Economics, 206, 79-92.

Chima, C. M. (2007). Supply-chain management issues in the oil and gas industry. Journal of Business \& Economics Research (JBER), 5(6).

Chow, W. S., Madu, C. N., Kuei, C. H., Lu, M. H., Lin, C., \& Tseng, H. (2008). Supply chain management in the US and Taiwan: An empirical study. Omega, 36(5), 665-679.

Clemons, R., \& Slotnick, S. A. (2016). The effect of supply-chain disruption, quality and knowledge transfer on firm strategy. International Journal of Production Economics, 178, 169-186.

Cooper, M. C., \& Pagh, J. D. (1998). Supply chain management: implementation issues and research opportunitie"s. The international journal of logistics management, 9(2), 1-20.

Croson, R., Schultz, K., Siemsen, E., \& Yeo, M. L. (2013). Behavioral operations: the state of the field. Journal of Operations Management, 31(1-2), 1-5.

Darwish, S., Alzayed, S., \& Ahmed, U. (2020). How Women in Science can Boost Women's Entrepreneurship: Review and Highlights. International Journal of Innovation Creativity and Change, 14(1), 453-470.

Davis, L. (2007). Exploring future competitive advantage through sustainable supply chains. International Journal of Physical Distribution \& Logistics Management.

De Guimaraes, J. C. F., Severo, E. A., Henri Dorion, E. C., Coallier, F., and Olea, P. M. (2016). The use of organizational resources for product innovation and organizational performance: a survey of the Brazilian furniture industry, International Journal of Production Economics, Vol. 180 No. 3, pp. 135-147.

Flynn, B. B., Huo, B., \& Zhao, X. (2010). The impact of supply chain integration on performance: A contingency and configuration approach. Journal of operations management, 28(1), 58-71.

Frohlich, M. T., \& Westbrook, R. (2001). Arcs of integration: an international study of supply chain strategies. Journal of operations management, 19(2), 185-200. 
Geyer, R., \& Jackson, T. (2004). Supply loops and their constraints: the industrial ecology of recycling and reuse. California Management Review, California, 46(2), 55-73.

Groznik, A., \& Trkman, P. (2006). A case study of supply chain management in oil industry. In 28th International Conference on Information Technology Interfaces, 2006. (pp. 531536). IEEE.

Gundlach, G. T., Frankel, R., \& Krotz, R. T. (2019). Competition policy and antitrust law: implications of developments in supply chain management. Journal of Supply Chain Management, 55(2), 47-67.

Han, J., Omta, S. W. F., \& Trienekens, J. H. (2007). The joint impact of Supply Chain Integration and Quality Management on the performance of Pork processing firms in China. International Food and Agribusiness Management Review, 10(2), 67-98.

Handfield, R. B., \& Nichols, E. L. (2002). Supply chain redesign: Transforming supply chains into integrated value systems. Ft Press.

Harvey, J. (2016). Urban land economics. Macmillan International Higher Education.

Hines, T. (2004). Supply chain strategies: Customer driven and customer focused. Routledge.

Hong, P., \& Jeong, J. (2006). Supply chain management practices of SMEs: from a business growth perspective. Journal of Enterprise Information Management.

Hyland, P., \& Beckett, R. (2002). Learning to compete: the value of internal benchmarking. Benchmarking: An International Journal.

Kapoor, R., \& Adner, R. (2012). What firms make vs. what they know: how firms' production and knowledge boundaries affect competitive advantage in the face of technological change. Organization Science, 23(5), 1227-1248.

Kessler, E. H., \& Chakrabarti, A. K. (1996). Innovation speed: A conceptual model of context, antecedents, and outcomes. Academy of Management Review, 21(4), 1143-1191.

Lambert, D. M., Cooper, M. C., \& Pagh, J. D. (1998). Supply chain management: implementation issues and research opportunities. The international journal of logistics management, 9(2), 1-20.

Li, S., Ragu-Nathan, B., Ragu-Nathan, T. S., and Rao, S. S. (2006). The impact of supply chain management practices on competitive advantage and organizational performance, Omega, Vol. 34 No. 2, pp. 107-124.

Malaysia, \& Malaysia. Kementerian Perdagangan Antarabangsa \& Industri. (2007). The Second Industrial Master Plan, 1996-2005. Ministry of International Trade and Industry, Malaysia.

Malaysian Investment Development Authority (2007). "Performance Of The Manufacturing And Services Sectors". Retrieved from https://www.mida.gov.my/.

Min, S., \& Mentzer, J. T. (2015). Developing and measuring supply chain management concepts. Journal of business logistics, 25(1), 63-99.

Narayanan, A., \& Moritz, B. B. (2015). Decision making and cognition in multi-echelon supply chains: An experimental study. Production and Operations Management, 24(8), 12161234.

Narasimhan, R., \& Kim, S. W. (2002). Effect of supply chain integration on the relationship between diversification and performance: evidence from Japanese and Korean firms. Journal of operations management, 20(3), 303-323.

Näslund, D., \& Hulthen, H. (2002). Supply chain management integration: a critical analysis. Benchmarking: An International Journal. 
Okongwu, U., Brulhart, F., \& Moncef, B. (2015). Causal linkages between supply chain management practices and performance: a balanced scorecard strategy map perspective. Journal of Manufacturing Technology Management, 26(5), 678-702.

Porter, M. E. (2012). Competitive advantage of nations: creating and sustaining superior performance.

Pandari, R. A., \& Azar, A. (2017). A fuzzy cognitive mapping model for service supply chains performance. Measuring Business Excellence, 21(4), 388-404.

Reuter, C., Foerstl, K. A. I., Hartmann, E. V. I., \& Blome, C. (2010). Sustainable global supplier management: the role of dynamic capabilities in achieving competitive advantage. Journal of Supply Chain Management, 46(2), 45-63.

Scherrer-Rathje, M., Boyle, T. A., \& Deflorin, P. (2009). Lean, take two! Reflections from the second attempt at lean implementation.. Business horizons, 52(1), 79-88.

Schmitt, T. G., Kumar, S., Stecke, K. E., Glover, F. W., \& Ehlen, M. A. (2017). Mitigating disruptions in a multi-echelon supply chain using adaptive ordering. Omega, 68, 185198.

Soosay, C. A., Hyland, P. W., \& Ferrer, M. (2015). Supply chain collaboration: capabilities for continuous innovation. Supply chain management: An international journal, 13(2), 160169.

Swink, M. L. (2015). Delivering successful supply chain innovations: lessons from CSCMP's supply chain innovation award winners. CSCMP Explores, 12(4), 1-14.

Tan, K. H., Zhan, Y., Ji, G., Ye, F., \& Chang, C. (2015). Harvesting big data to enhance supply chain innovation capabilities: An analytic infrastructure based on deduction graph. International Journal of Production Economics, 165, 223-233.

Taghipour, M., Bagheri, M., Khodarezaei, M., \& Farid, F. (2015). Supply chain performance evaluation in the IT industry. International Journal of Research and Reviews in Applied Sciences, 23(2), 144.

Tarafdar, M., \& Qrunfleh, S. (2017). Agile supply chain strategy and supply chain performance: complementary roles of supply chain practices and information systems capability for agility. International Journal of Production Research, 55(4), 925-938.

Teece, D. J. (2010). Business models, business strategy and innovation. Long range planning, 43(2-3), 172-194.

Thaler, R. H. (2016). Behavioural economics: Past, present, and future. American Economic Review, 106(7), 1577-1600.

Thatte, A. A. (2007). Competitive advantage of a firm through supply chain responsiveness and SCM practices. (Doctoral dissertation, University of Toledo).

Udomleartprasert, P., \& Jungthirapanich, C. (2003). The Operational Infrastructure Enhancing the Supply Chain Management. In International Conference of Electronic Business, Singapore.

Vachon, S. (2007). Green supply chain practices and the selection of environmental technologies. International Journal of Production Research, 45(18-19), 43574379.

Wang, M. (2018). Impacts of supply chain uncertainty and risk on the logistics performance. Asia Pacific Journal of Marketing and Logistics, 30(3), 689-704.

Yamin, S., Gunasekaran, A., and Mavondo, F.T. (1999). Relationship between generic strategies, competitive advantage and organizational performance: an empirical analysis, Technovation, Vol. 19 No. 8, pp. 507-518.

Yunis, M., El-Kassar, A. N., \& Tarhini, A. (2017). Impact of ICT-based innovations on organizational performance. Journal of Enterprise Information Management. 
Sundram, V. P. K., Atikah, S. B., Zarina, A. M., \& Zolait, A. H. (2018). The effect of supply chain information management and information system infrastructure: The mediating role of supply chain integration towards manufacturing performance in Malaysia. Journal of Enterprise Information Management, Vol. 31 (5), 751-770.

Sundram, V. P. K., Rajagopal, P., Nur Atiqah, Z. A., Atikah, S. B., Appasamy, G., \& Zarina, A. M. (2018). Supply Chain Responsiveness in an Asian Global Electronic Manufacturing Firm: ABX Energy (M), International Journal of Supply Chain Management, Vol. 7, (2), 23-31.

Sundram, V. P. K., Rajagopal, P., Atikah, S. B., \& Subramaniam, G. (2018). The Role of Supply Chain Integration on Green Practices and Performance in a Supply Chain Context: A Conceptual Approach to Future Research, International Journal of Supply Chain Management, Vol. 7, (1), 95-104.

Sundram, V. P. K, Atikah, S. B., Akmal, A. O., \& Zarina, A. M. (2017). Green Supply Chain Management Practices in Malaysia Manufacturing Industry. International Journal of Supply Chain Management, Vol. 6, (2), 89-95.

Selvaraju, M., Beleya, P., \& Sundram, V. P. K. (2017). Supply Chain Cost Reduction using Mitigation \& Resilient Strategies in the Hypermarket Retail Business, International Journal of Supply Chain Management, Vol. 6 (2), 116-121.

Sundram, V. P. K., Chandran, V. G. R., \& Bhatti, M. A. (2016). Supply chain practices and Performance: the indirect effects of supply chain integration, Benchmarking: An International Journal. Vol. 23 No. 6, 1445-1471.

Rajagopal, P., Nur Atiqah, Z. A., Atikah, S. B., Appasamy, G., \& Sundram, V. P. K. (2016). Determinants of Supply Chain responsiveness among Firms in the Manufacturing Industry in Malaysia., International Journal of Supply Chain Management, Vol. 5, (3).

Stock, G. N., Greis, N. P., \& Kasarda, J. D. (2012). Enterprise logistics and supply chain structure: the role of fit. Journal of operations management, 18(5), 531-547.

Zimmermann, R., DF Ferreira, L. M., \& Moreira, C. A. (2016). The influence of supply chain on the innovation process: a systematic literature review. Supply Chain Management: $A n$ International Journal, 21(3), 289-304.

Zhang, L. P., \& Tian, P. (2001). Information Sharing Incentive In Supply Chain-A Dynamic Model [J]. Chinese Journal of Management Science, 1.

Zhen., He, Z., \& Jiang, B. (2016). Competitive collection under channel inconvenience in closed-loop supply chain. European Journal of Operational Research, 275(1), 155-166. 2016. 